\title{
Bio-controller Effect of Four Native Strains of Trichoderma spp., on Phytophthora capsici in Manzano Chili (Capsicum pubescens) in Puebla- Mexico
}

\author{
Ma. Ángeles Valencia de Ita ${ }^{1} \mathbb{D}$, Jiménez Huerta Fátima ${ }^{2}$, Conrado Parraguirre \\ Lezama $^{1}(\mathbb{D})$, Alfredo Báez Simón ${ }^{1}\left(\mathbb{D}\right.$, Gerardo Landeta Cortés ${ }^{3}$ (D) and \\ Omar Romero-Arenas ${ }^{1 *}$ (ic
}

${ }^{1}$ Agroecology Center, ICUAP, Benemerita Universidad Autonoma de Puebla (BUAP), Mexico.

${ }^{2}$ Superior Technological Institute of Tlatlauquitepec, Puebla, Mexico.

${ }^{3}$ University Center for Technology Linkage and Transfer, BUAP-CONACyT, Mexico.

\begin{abstract}
Diversity of the different types of chilies in Mexico has been scarcely studied, and a large variety have been found to be, such as Manzano chili. Root rot caused by oomycete Phytophthora capsici is a severe disease that affects Manzano chili production in Mexico, detracted from its production and quality. The use of biological control agents such as Trichoderma native's species, represents an efficient alternative to reduce losses and control the disease. For this reason, the objective of the present investigation was to evaluate the antagonistic effect In vitro and In vivo of four native strains of Trichoderma spp., on Phytophthora capsici in seedlings of Manzano chili from Puebla-Mexico was evaluated. Dual culture technique was used to determine the percentage of inhibition of radial growth (PICR) of the PC-A strain of $P$. capsici. Analysis of the percentage of germination was also carried out, as well as the incidence of root rot at $\mathbf{2 0}$ days after inoculation with the pathogen (dai) in the nursery. T. harzianum strain presented the highest PICR (42.86\%) of antagonistic level in vitro and class I in the Bell scale, in addition, it obtained $88 \%$ germination in the nursery and $10 \%$ mortality at 20 dai, higher than the other native strains of Trichoderma. The bio-controlling effect of strains of Trichoderma spp., offers an effective alternative for root necrosis caused by $P$. capsici in the cultivation of Manzano chili in Puebla-Mexico.
\end{abstract}

Keywords: Antagonism, incidence of rot, PICR, nursery, mortality

*Correspondence: biol.ora@hotmail.com

(Received: March 26, 2021; accepted: May 05, 2021)

Citation: Ita MÁVD, Fátima JH, Lezama CP, Simón AB, Cortés GL, Romero-Arenas O. Bio-controller Effect of Four Native Strains of Trichoderma spp., on Phytophthora capsici in Manzano Chili (Capsicum pubescens) in Puebla-Mexico. J Pure Appl Microbiol. 2021;15(2):998-1005. doi: 10.22207/JPAM.15.2.58

(C) The Author(s) 2021. Open Access. This article is distributed under the terms of the Creative Commons Attribution 4.0 International License which permits unrestricted use, sharing, distribution, and reproduction in any medium, provided you give appropriate credit to the original author(s) and the source, provide a link to the Creative Commons license, and indicate if changes were made. 


\section{INTRODUCTION}

Chili is a fundamental and representative ingredient of Mexican diet, and which is considered the first domesticated crop in the American continent. The Manzano chili (Capsicum pubescens) is native to upper parts of Peru and Bolivia, recently introduced in Mexico, favored by its ability to adapt to cold places, where no other type of chili thrives ${ }^{1}$.

The Manzano chili is distributed in Sierra Norte of state of Puebla, specifically in the municipalities of Tlatlauquitepec, Zacapoaxtla and Teziutlan; as well too in Tacambaro and Zitacuaro in Michoacan; Huatusco, Coscomatepec and Zongolica in Veracruz; Coatepec, Villa Guerrero and San Miguel Tlaixpan in the Edo. Mexico; Finally, San Cristobal and Motozintla in the State of Chiapas ${ }^{2}$, in addition the Manzano chili has great gastronomic, economic and social importance as it is a basic ingredient of traditional food ${ }^{3}$.

Currently the production of the Manzano chili in the region of Tlatlauquitepec is compromised by presence to fungal diseases. The diseases with the highest incidence in seedling stage of genus Capsicum are caused by pathogens such as Rhizoctonia sp., Fusarium spp. and Phytophthora sp., which cause the loss of more than a third of the crop production, where the main symptom is premature plant death, damage to reproductive structures and irregular root-rot ${ }^{4,5}$. However, basal root production caused by oomycete $P$. capsici, Leonian is the most lethal ${ }^{6}$. The disease occurs in roots, stems, leaves and fruits ${ }^{7}$, being one of the most destructive diseases worldwide for the cultivation of chilis.

Chemical synthesis products have been used for decades to control these diseases ${ }^{9}$. However, its use is related to generation of resistance fungal, damage to environment and human health ${ }^{10}$. Under this premise, biological control is considered an efficient and friendly with the environment practice, for the development of sustainable agriculture ${ }^{11}$.

The use of filamentous fungi as biocontrol agents represents an effective alternative for agricultural production systems because it reduces numerous applications of various types of fungicides. For more than eight decades, research has been conducted on the use of different species of Trichoderma ${ }^{12,13}$. Multiple mechanisms of action have been described, but the most relevant are (a) the production of secondary metabolites that strengthen the plant's immune system ${ }^{14,15}$, (b) the action of natural mycoparasites and antagonistic agents and (c) the promotion of seed germination and plantgrowth, as well as an increased root and foliage biomass and mineral assimilation; thus, different indigenous species of Trichoderma play an important role in agroforestry and natural ecosystems; they are considered biological control agents ${ }^{16}$ because they act against pathogens of agroecology importance.

Consequently, the objectives of this research work were: A) Determine antagonistic capacity and percentage of inhibition of radial growth in vitro of four native strains of Trichoderma spp., upon PC-A strain of P. capsici; B) Analyze percentage of germination and root rot of Manzano chili seedlings at 20 days after pathogen inoculation in nursery.

\section{MATERIALS AND METHODS}

\section{Antagonism of native strains of Trichoderma spp., on $P$. capsici in dual cultures}

Evaluation of antagonism was carried out with the native strains of $T$. harzianum, $T$. viridae, T. atroviridae and T. hamatum, likewise the PC-A strain of $P$. capsici was used. All biological material is protected in laboratory 204 of Eco-Campus Valsequillo of Instituto de Ciencias, Benemérita Universidad Autonoma de Puebla (BUAP).

For evaluation of mycelial development, fragments of $5 \mathrm{~mm}$ diameter native strains of Trichoderma spp., as well as the PC-A strain of $P$. capsici (5 $\mathrm{mm}$ diameter), were inoculated in Petri dishes with potato and dextrose agar (PDA) incubated under darkness at $28{ }^{\circ} \mathrm{C}$ for 10 days. Mycelial diameter was measured every $12 \mathrm{~h}$ to estimate the growth speed $(\mathrm{cm})$, which was calculated with the linear growth function $y=$ $m x+b$ (where ' $y$ ' is the distance, ' $x$ ' is the time and ' $b$ ' the constant factor) and was expressed in centimeters per day $\left(\mathrm{cm} \mathrm{d}^{-1}\right)^{17}$. Diameter was determined with a digital Vernier (CD-6 Mitutoyo) always in the same direction in triplicate, which was established at random for each repetition.

Dual culture technique was used according to Andrade-Hoyos et al. ${ }^{10}$ in triplicate to determine percentage of inhibition of radial growth with formula PICR $=[(R 1-R 2 / R 1) \times 100]$ 
for each assay evaluated for a period of 10 days. To complement the evidence of antagonism, each trial was compared and classified in one of the 5 levels of grade scale (Table 1) established by Bell ${ }^{18}$. And thus, obtain qualitative evidence of the antagonistic effect.

Nursery tests to analyze the percentage of germination and incidence of root rot

Manzano chili 3,600 seeds were used provided by producers from Huaxtla community belonging to the municipality of Tlatlauquitepec, Puebla-Mexico. The trial was carried out under controlled conditions in nursery of EcoCampus Valsequillo, ICUAP-BUAP. Prior to seed germination; these were disinfected with $0.3 \%$ sodium hypochlorite (v/v) for $10 \mathrm{~min}$, rinsed three times with sterile water and dried with sterile paper ${ }^{19}$.Was infested strain PC-A of $P$. capsici in 600 seeds per palate for each treatment under study; was prepared in a sterile saline suspension at a concentration of $1 \times 10^{8}$ zoospores $\mathrm{mL}^{-1}$ by means of a Neubauer chamber (PAUL MARIENFELD) ${ }^{20}$. Once pathogen was soaked and the seeds were dry, of native strains of Trichoderma spp., were inoculated. This was carried out with a suspension of teliospores at a concentration of $1 \times 10^{8}$ conidia $\mathrm{mL}^{-1}$ for all separate treatments, each one with 600 seeds.

Once the treatments were inoculated, seeds were placed in germinating trays with Peatmoss and Agrolita (1:1 v/v), previously sterilized at $121 \stackrel{\circ}{\circ}$ and $15 \mathrm{lb}$ pressure ${ }^{21}$. Seeds were sown through a standardized mechanical procedure; the wet substrate was deposited at three quarters of total cavity capacity, one seed per cavity was placed at a depth of $1 \mathrm{~cm}^{22}$. A control group was used; which consisted of seeds disinfected in a sterile solution of distilled water and $3 \%$ sucrose. Finally, the trays were covered with black plastic for 20 days at $27^{\circ} \mathrm{C}$ for germination ${ }^{22}$. Seed germination percentages were calculated according to following formula: Seed germination $(\%)=$ (number of germinated seeds / total number of seeds) $\times 100^{23}$. The data were taken when the control group presented $\geq 90 \%$ germination.

The degree of incidence of root rot was quantified by the damage that the seedlings presented throughout 20 days after inoculation (dai) for this a scale (Table 2) of general aspects modified from the one used by Sobrino ${ }^{24}$ is formulated, where each treatment consists a germinating tray of 200 cavities in triplicate $(n=$ 600).

\section{Statistical analysis}

The analysis of variance (two-way ANOVA) of response variables and comparison tests of means by LSD Tukey-Fisher $(\alpha=0.05)$ was carried out, using statistical package IBM SPSS Statistics version 25 .

\section{RESULTS AND DISCUSSION}

There were zones of interaction between native strains of Trichoderma spp., against P. capsici, where parasitism was observed at $142 \mathrm{~h}$. Development rate and growth speed showed significant differences ( $p \geq 0.05$ ), where T. harzianum obtained highest value (Table 3 ) with $1.27 \pm 0.08 \mathrm{~mm} / \mathrm{h}$ and $1.52 \pm 0.02 \mathrm{~cm} \delta^{-1}$, respectively. Results similar to those reported by Morales et al. ${ }^{25}$ where it reports a growth speed for T. harzianum (TH-4) of $1.86 \pm 0.22 \mathrm{~cm} \mathrm{~d}^{-1}$ and 1.67 $\pm 0.01 \mathrm{~mm} / \mathrm{h}$. The pathogen $P$. capsici obtained lowest growth speed $\left(0.67 \pm 0.06 \mathrm{~cm} \mathrm{~d}^{-1}\right)$, higher results than those reported by Andrade-Hoyos et al. ${ }^{10}$ where they show that growth rate is different in species of pathogens, including $P$. capsici.

Percentage of inhibition radial growth (PICR) shows significant differences $(p<0.014)$, however, antagonistic strains show between 23 and $42 \%$ inhibition (Table 3 ). It was observed that T. harzianum and T. hamatum were more efficient than $T$. viridae and T. atroviridae, for which they obtained values of 33.33 and $23.63 \%$ respectively; however, T. harzianum presented a class I classification and T. hamatum presented a class II classification according to the scale established by Bell ${ }^{18}$.

The present investigation coincides with a study carried out by Ezziyyani et al. ${ }^{26}$ where it inhibited $50 \%$ of mycelial growth of $P$. capsici in pepper plants, proving the antagonistic effect in vitro of $T$. harzianum. Similarly, Zegeye et al. ${ }^{27}$ found that $T$. viride showed a complete inhibition in radial growth of $P$. infestansin vitro tests. In addition, they mentioned that foliar application of $T$. viride has good potential to control $P$. infestans under greenhouse conditions. Stefanova et al. ${ }^{28}$ reported presence of non-volatile metabolites with antifungal activity in four isolates of Trichoderma 
and concluded that they reduce the mycelial growth of $P$. nicotianae. This indicates that probably the species of the genus Trichoderma may have a higher nutrient incorporation rate and metabolism than $P$. capsici, as well as different secretion mechanisms of hydrolytic enzymes; among them cellulases, chitinases, glucanases, xylases and proteases, which may be involved in biocontrol mechanisms, allowing it to take better advantage of the nutrients in the environment and deprive the pathogen of using resources ${ }^{29}$.
Mycoparasitism is another of action mechanisms of the genus Trichoderma, in this research, it was possible to observe granulation of the PC-A strain of P. capsici and mycoparasitism between hyphae (strangulation) induced by T. harzianum (Fig. 1), this reaffirms the high mycoparasitic capacity of TH-4 strain. T. harzianum, which is capable of inhibiting the growth of phytopathogens because it produces numerous antibiotics such as trichodermine, suzukacillin,

Table 1. Bell $1^{17}$ antagonism scale.

\section{Class Features}

I Growth of Trichoderma spp., which covered entire surface of medium and reduced pathogen colony.

II Growth of Trichoderma spp., which covered at least 2/3 parts of medium.

III Trichoderma spp., and pathogen they grew $1 / 2$ and $1 / 2$ surface of medium, one did not overlap other.

IV Pathogenic fungus grew at least $2 / 3$ parts of medium and resisted invasion of Trichoderma spp.

$\mathrm{V} \quad$ Growth of pathogen that covered the entire surface of medium.

Table 2. Incidence scale of root rot in Manzano chili seedlings caused by $P$. capsici.

\begin{tabular}{lcc}
\hline Value & Percentage(\%) & Hurt \\
\hline 0 & 0 & Healthy plant \\
1 & 10 & Mild symptoms \\
2 & 50 & Severe symptoms \\
3 & 75 & Very severe symptoms \\
4 & 100 & Dead plant
\end{tabular}

*Evaluation carried out on a scale graduated from 0 (no symptoms in 600 plants) to 4 (600 dead plants). alameticin, dermadin, penicillin, trichothecenes, trichorzianines, among others ${ }^{16}$. In other strains of Trichoderma spp., it was not possible to observe any interaction mechanism.

The results corroborated what was reported by González et al. ${ }^{30}$ and Hyder et al. ${ }^{31}$ on enzymatic degradation of cell wall of phytopathogenic fungi during the mycoparasitic action; which causes lysis and with-it disorganization of cytoplasmic content and lysis of the cells.

Table 3. Development rate, growth speed, percentage of radial growth inhibition and antagonism classification on Bell Scale ${ }^{18}$

\begin{tabular}{|c|c|c|c|c|}
\hline Name & $\begin{array}{l}\text { Development } \\
\text { rate } \\
\text { (mm/hour)* }\end{array}$ & $\begin{array}{l}\text { Growth } \\
\text { rate } \\
\left(\mathrm{cm} \mathrm{d}^{-1}\right)^{*}\end{array}$ & $\mathrm{PICR} *$ & $\begin{array}{c}\text { Class } \\
\text { Bell }\end{array}$ \\
\hline T. harzianum & $1.27 \pm 0.08^{\mathrm{a}}$ & $1.52 \pm 0.02^{\mathrm{a}}$ & & \\
\hline T. viridae & $0.78 \pm 0.12^{b}$ & $1.23 \pm 0.06^{c}$ & & \\
\hline T. atroviridae & $0.83 \pm 0.08^{c}$ & $1.19 \pm 0.06^{d}$ & & \\
\hline T. hamatum & $0.61 \pm 0.12^{\mathrm{d}}$ & $1.46 \pm 0.02^{b}$ & & \\
\hline P. capsici & $0.59 \pm 0.14^{\mathrm{e}}$ & $0.67 \pm 0.06^{\mathrm{e}}$ & & \\
\hline P. capsici vs T. harzianum & & & $42.86 \pm 0.27^{a}$ & I \\
\hline P. capsici vs T. viridae & & & $33.33 \pm 0.012^{c}$ & ॥ \\
\hline P. capsici vs T. atroviridae & & & $23.63 \pm 0.042^{\mathrm{d}}$ & III \\
\hline P. capsici vs T. hamatum & & & $37.62 \pm 0.40^{\mathrm{b}}$ & II \\
\hline
\end{tabular}

*Different letters mean significant difference between treatments according to Tukey-Kramer $(p \leq 0.05)$. 
Antagonism tests reflect the ability and genetic variability of antagonist and phytopathogen to resist antagonism, this allows preliminary selection to be evaluated under field conditions, as well as to complement and determine their bio-controlling capacity ${ }^{25}$.

Germination of seeds of Manzano chili in control group was presented at 14 days with $93 \%$, where significant differences $(p=0.023)$ were presented with respect to the other treatments (Fig. 2), where the effect of inoculation was

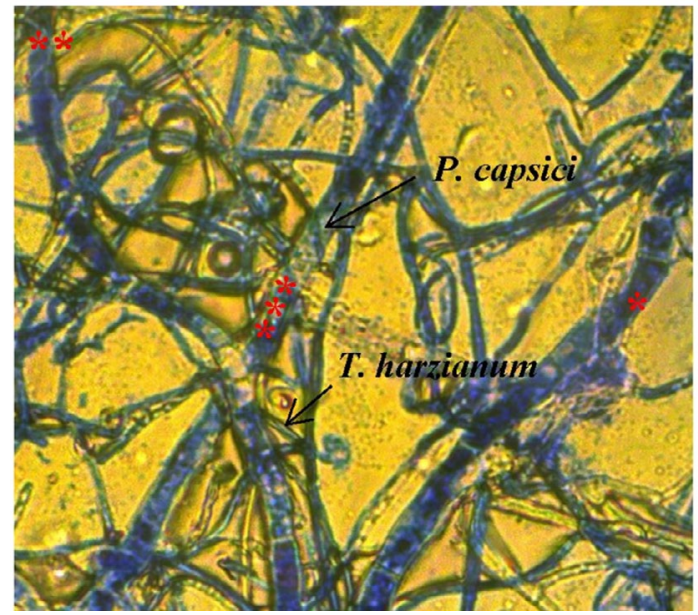

Fig. 1. Mycoparasitism of T. harzianum on the hyphae of $P$. capsici, *hypha swelling, **hypha curl, ${ }^{* * *}$ granulations within hypha observed of $P$. capsici, which affected germination percentage (23.45\%). Huallanca et al. ${ }^{32}$ mention that $P$. capsici pseudo-fungus inoculated in chili seedlings produced secondary symptoms of wilting, yellowing and ascending death; as well as primary symptoms of neck rot and root rot. Madhavi et al. ${ }^{33}$ reported a germination percentage of $90.3 \%$ in chili (Capsicum annuum) seedlings inoculated with $T$. harzianum in greenhouse, results similar to those found in the present investigation.

Microbial antagonists significantly reduced seed infection in Manzano chili caused by $P$. capsici, likewise a significant increase in seed germination was recorded in treatments of $T$. harzianum and T. hamatum, while treatment with strains of $T$. viridae and T. atroviridae, reduced seed mortality by $70 \%$ compared to the pathogen (PC-A strain).

The results showed treatments presented bio-controller activity were effective in reducing incidence of wilt and root rot disease in Manzano chili plants under induced infection (Figure 3). Treatments with native strains of Trichoderma reduced the disease $90 \%$ in relation to the pathogen, which reached very severe symptoms, in which incidence obtained was 1.6, 1.4, 1.3, 1.2 and 3.8 respectively.

In untreated seedlings (Control) they presented a natural incidence of the pathogen, which reached an average of 1.6 on scale used,

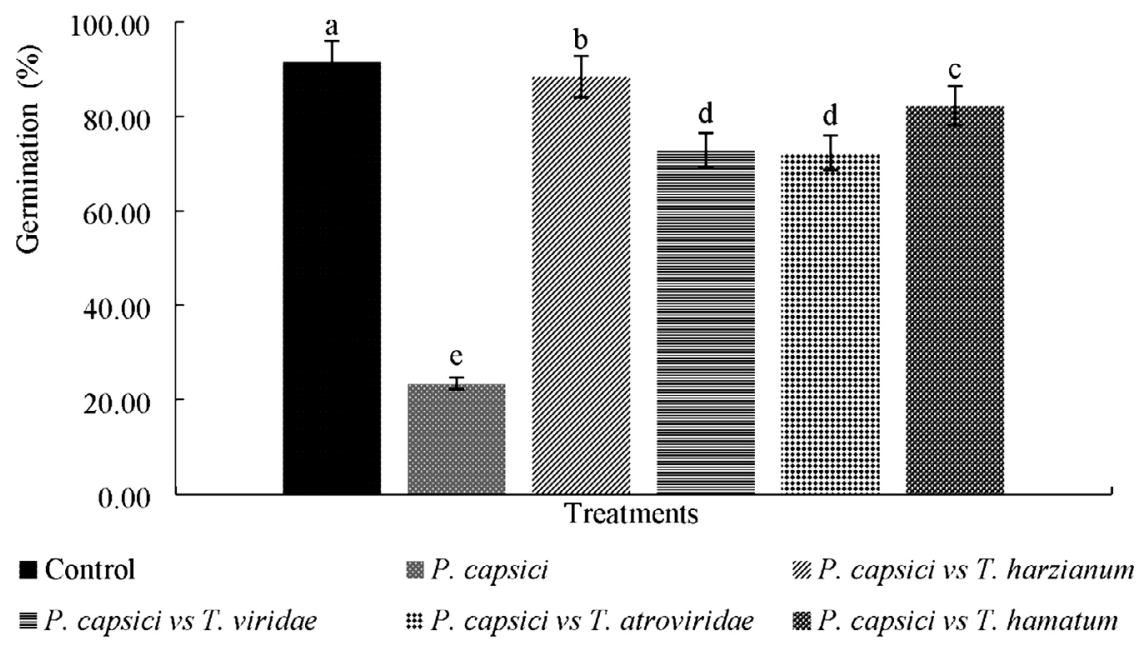

Fig. 2. Comparison of Germination Percentage of Manzano chili seeds inoculated with native strains of Trichoderma spp., and $P$. capsici in nursery.*Different letters mean significant difference between treatments according to Tukey-Kramer $(p \leq 0.05)$ 


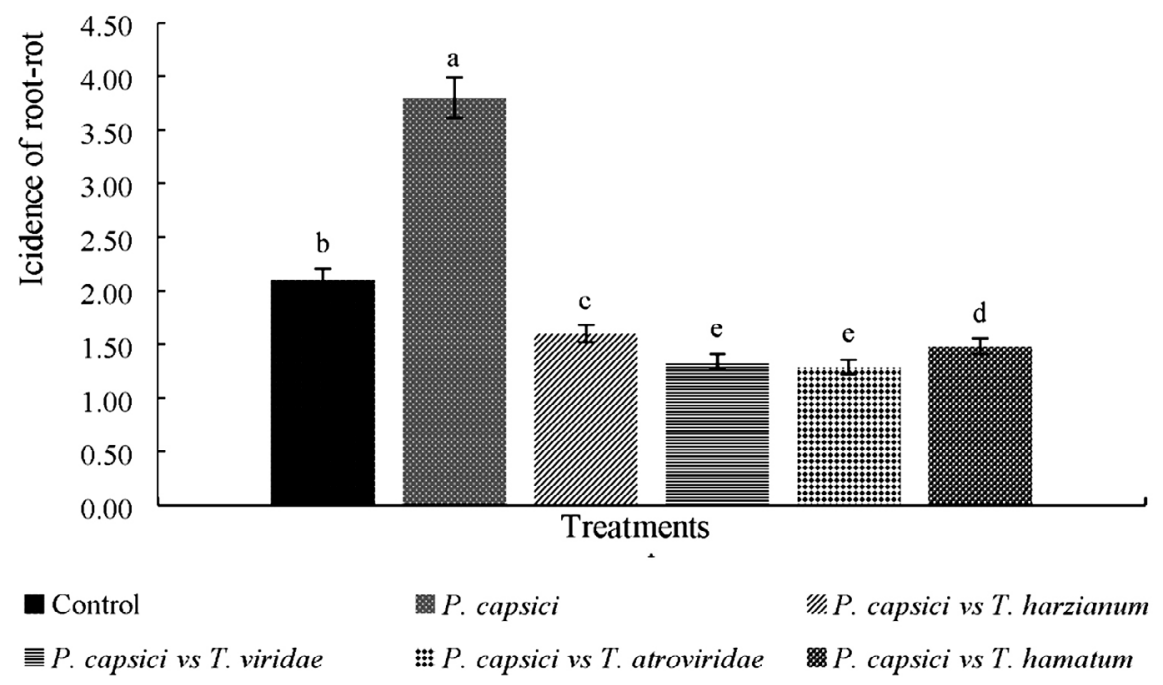

Fig. 3. Comparison of incidence of root rot in Manzano chili(Capsicum pubescens) seedlings germinated from seeds treated with native strains of Trichoderma spp. and $P$. capsici in nursery 20 dai. ${ }^{*}$ Different letters mean significant difference between treatments according to Tukey-Kramer $(p \leq 0.05)$

which tells us that plants used by the producers present some natural contamination and are mostly affected with symptoms ranging from mild to severe, that is why, they the producers of the study region are looking for an efficient control method.

The Manzano chili seedlings that were inoculated with $P$. capsici showed root rot at 20 dai, this coincided with that described by Agrios $^{34}$ when discovering rot caused by $F$. solanifor the cultivation of chili. Ezziyyani et al. ${ }^{26}$ applied $T$. harzianum on $P$. capsici, reducing wilting between 22 and $56 \%$. Results inferior to those reported in present investigation.

Andrade-Hoyos et al. ${ }^{16}$, where they attribute effect on growth not only to protection against pathogens, but also to presence of a growth regulating factor in plants ${ }^{30} . T$. harzianum possesses the ability to solubilize various plant nutrients from their insoluble or poorly soluble mineral phases through chelating and reducing mechanisms; due to these mechanisms it is that phosphates (mainly calcium), $\mathrm{Fe}_{2} \mathrm{O}_{3}, \mathrm{MnO}_{2}, \mathrm{Cu}$ and $\mathrm{Zn}$, tend to be more assimilated by plants ${ }^{30}$.

The genus Trichoderma can parasitize pathogenic fungi and produce antibiotics, in addition, it has positive effects on plant growth, yield, nutrient absorption, efficiency in use of fertilizers and systemic resistance to plant diseases $^{16,30}$.

\section{CONCLUSIONS}

Native strains of $T$. harzianum and T.hamatum showed greater antagonism on $P$. capsici in the Bell's scale, however, T. harzianum showed higher PCIR in vitro conditions.

Under nursery conditions, all antagonistic strains showed a better response in germination of Manzano chili plants. However, T. harzianum presented the highest germination percentage (88\%) followed by T. hamatum (82\%).

PC-A strain of $P$. capsici caused up to $90 \%$ root rot to the 20 days after inoculation with the pathogen in nursery.

\section{ACKNOWLEDGMENTS}

The authors thank the Office of Vicerrectoria de Investigacion y Posgrados de la Universidad Autonoma Benemerita de Puebla (BUAP) for the financial support for this research project, as well as CONACYT-Mexico, for the support received.

\section{CONFLICT OF INTEREST}

The authors declare that there is no conflict of interest. 


\section{AUTHORS' CONTRIBUTION}

All authors listed have made a substantial, direct and intellectual contribution to the work, and approved it for publication.

\section{FUNDING}

This work is funded by the Benemerita Universidad Autonoma de Puebla, Mexico, the Secretary of Public Education (SEP), Funding Program for publications for desirable profile.

\section{DATA AVAILABILITY}

All datasets generated or analyzed during this study are included in the manuscript and/or the Supplementary Files.

\section{ETHICS STATEMENT}

This article does not contain any studies with human participants or animals performed by any of the authors.

\section{REFERENCES}

1. Espinosa-Torres LE, Ramlrez-Abarca O. Rentabilidad de chile manzano (Capsicum pubescens R Y P) producido en invernadero en Texcoco, Estado de Mexico. Revista Mexicana de Ciencias Agricolas. 2016;7(2):325-335. doi: 10.29312/remexca.v7i2.347

2. Espinosa LE. Cultivo en invernadero, postcosecha y mercado de chile manzano (Capsicum pubescens). Tesis de doctorado en ciencias en horticultura. Universidad Autonoma Chapingo. Chapingo, Estado de Mexico. 2010.

3. Perez-Carrasco LJ, Tornero-Campante MA, EscobedoGarrido JS, Sandoval-Castro E. El chile poblano criollo en la cultura alimentaria del Alto Atoyac. Estudios Sociales. 2017;27(49):47-66. http://www. scielo.org.mx/pdf/estsoc/v27n49/0188-4557estsoc-27-49-00047.pdf

4. Rivera-Jimenez MN, Zavaleta-Mancera HA, RebollarAlviter A, et al. Phylogenetics and histology provide insight into damping-off infections of 'Poblano' pepper seedlings caused by Fusarium wilt in green houses. Mycological Progress. 2018;17:1237-1249. doi: 10.1007/s11557-018-1441-2

5. Guenoun K, Chattaoui M, Bouri M, Rhouma A, Naghmouchi K, Raies A. Biological control of growth promoting rhizobacteria against verticillium wilt of pepper plant. Biologia. 2019;74:237-250. doi: 10.2478/ s11756-018-00169-9

6. Bhusal B, Mmbaga MT. Biological control of Phytophthora blight and growth promotion in sweet pepper by Bacillus species. Biological Control. 2020;150: 104373. doi: 10.1016/j.biocontrol.2020.104373

7. Naegele PR, Hausbeck KM. Phytophthora root rot resistance and its correlation with fruit rot resistance in Capsicum annuum. Hort Science. 2020;55(12);19311937.doi: $10.21273 /$ HORTSCI15362-20
8. Retes-Manjarrez JE, Rubio-Aragon WA, MarquesZequera I, Cruz-Lachica I, Garcia-Estrada RS, Sy O. Novel Sources of Resistance to Phytophthora capsici on Pepper (Capsicum sp.) Landraces from Mexico. The Plant Pathology Journal. 2020;36(6):600607. doi: 10.5423/PPJ.OA.07.2020.0131

9. Gan H, Wickings K.Soil ecological responses to pest management in golf turf vary with management intensity, pesticide identity, and application program. Agriculture, Ecosystems and Environment. 2017;246:66-77. doi: 10.1016/j.agee.2017.05.014

10. Andrade-Hoyos P, Luna-Cruz A, Hernandez EO, Gayosso EM, Valenzuela NL, Cureno HJB. Antagonismo de Trichoderma spp., vs hongosasociados a la marchitez de chile. Revista Mexicana de Ciencias Agricolas. 2019;10(6):1259-1272. doi: 10.29312/remexca. v10i6.1326

11. Perez-Torres E, Bernal-Cabrera A, Milanes-Virelles $\mathrm{P}$, et al. Eficiencia de Trichoderma harzianum (cepa a-34) y sus filtrados en el control de tres enfermedades fungicas foliares en arroz. Bioagro. 2018;30(1):17-26. doi: 10.1080/21501203.2017.142312

12. Romero-Arenas O, Amaro LJ, Damian HM, Valencia de Ita MA, Huerta ARM. Bio-preparados de Trichoderma spp., para el control biologico de Phytophthora capsici en el cultivo de tomate de Puebla, Mexico. ITEA. 2017;113(4):313-324. doi: 10.12706/itea.2017.019

13. Launio CC, Labon KO, Banez AM and Batani RS. Adoption and economic analysis of using biological control in Philippine highland farms: Case of Trichoderma koningii strain KA. Crop Protection. 2020;136:e105177. doi: 10.1016/j.cropro.2020.105177

14. Nawrocka J, Małolepsza U, Szymczak K, Szczech $M$. Involvement of metabolic components, volatile compounds, proteins, and mechanical strengthening in multilayer protection of cucumber plants against Rhizoctonia solani activated by Trichoderma atroviride TRS25. Protoplasma. 2018;255(1):359-373. doi: 10.1007/s00709-017-11571-1

15. Hernandez-Melchor DJ, Ferrera-Cerrato R, Alarcon A. Trichoderma: importancia agricola, biotecnologica y sistemas de fermentacion para producir biomasa y enzimas de interes industrial. Chilean Journal of Agricultural and Animal Sciences. 2019;35(1):98-112. doi: 10.4067/S0719-38902019005000205

16. Andrade-Hoyos P, Silva-Rojas HV, Romero-Arenas, O. Endophytic Trichoderma Species Isolated from Persea americana and Cinnamomum verum Roots Reduce Symptoms Caused by Phytophthora cinnamomi in avocado. Plants. 2020;9(9):e1220. doi: 10.3390/ plants9091220

17. Zeravakis G, Philippoussis A, Ioannidou S, Diamantopoulou P. Mycelium growth kinetics and optimal temperature conditions for the cultivation of edible mushroom species on lignocellulosic substrates. Folia Microbiologica, 2001;46(3):231e. doi: 10.1007/ BF02818539

18. Bell DK, Wells HD, Markham CR.In vitro antagonism of Trichoderma species against six fungal plant pathogens. Phytopathology. 1982;72:379-382. doi: 10.1094/Phyto-72-379

19. Illa C, Andres-Perez A, Matias T, Perez MA. Efecto 
de biocontrol y promoción del crecimiento en maní por Trichoderma harzianum y Bacillus subtilis en condiciones controladas y campo. Revista Mexicana de Fitopatologia. 2019;38(1):119-131. doi: 10.18781/R. MEX.FIT.1910-6

20. Reyes-Tena A, Rodriguez-Alvarado G, SantillanMendoza R, Diaz-Celaya M, Fernandez-Pavia SP. Marchitez causada por Fusarium solani en chile chilaca (Capsicum annuum) en Michoacan. Revista Mexicana de Fitopatologia, 2019;37(1):43-47. doi: 10.18781/R. MEX.FIT.1904-1

21. Mannai S, Jabnoun-Khiareddine $H$, Nasraoui B, Daami-Remadi M. Rhizoctonia root rot of pepper (Capsicumannuum): Comparative pathogenicity of causal agent and bio control attempt using fungal and bacterial agents. Journal of Plant Pathology and Microbiology, 2018;9(2): 431-439.doi: 10.4172/21577471.1000431

22. Castillo-Aguilar, C. de la C. Produccion de planta de chile habanero (Capsicum chinense Jacq.). Agro Productividad, 2015;8(4):73-78.

23. Al-Fadhal FA, Al-Abedy AN, Alkhafije DA. Isolation and molecular identification of Rhizoctonia solani and Fusarium solani isolated from cucumber (Cucumis sativus L.) and their control feasibility by Pseudomonas fluorescens and Bacillus subtilis.Egyptian Journal of Biological Pest Control. 2019;29:47. doi: 10.1186/ s41938-019-0145-5

24. Sobrino Rubio R. Tesisen Ciencias. Control biologico de Fusarium oxysporum f. sp. con antagonistas. Universidad Autonoma Chapingo. Chapingo, Estado de Mexico. 2005.

25. Morales-Mora LA, Andrade-Hoyos P, Ita MAV-de, Romero-Arenas O, Silva-Rojas HV, Contreras-Paredes CA. Caracterizacion de hongos asociados al cultivo de fresa y efecto antagonista in vitro de Trichoderma harzianum. Revista Mexicana de Fitopatologia. 2020;38(3):434-449. doi: 10.18781/R.MEX.FIT.2005-7

26. Ezziyyani M, Sanchez CP, Ahmed AS, Requena
ME, Castillo MEC. Trichoderma harzianum como biofungicida para el biocontrol de Phytophthoracapsici en plantas de pimiento (Capsicum annuum L.). Anales de Biologia. 2004;26:35-45.

27. Zegeye H, Teketay D, Kelbessa E. Diversity and regeneration status of woody species in Tara Gedam and Abebaye forests, northwestern Ethiopia. Journal of Forestry Research. 2011;22(3):315-328. doi: 10.1007/ s11676-011-0176-6

28. Stefanova M, Leiva A, Coronado F, Larrinaga L. Actividadmetabolica de cepas de Trichoderma spp. para el control de hongosfitopatógenos del suelo.Revista de la Facultad de Agronomia(LUZ). 1999;16:509-516.

29. Michel-Aceves AC, Otero-Sanchez MA, RebolledoDomínguez O, Lezama-Gutierrez R, Ariza-Flores R, Barrios-Ayala A. Produccion y efecto antagonico de quitinasas y glucanasas por Trichoderma spp., en la inhibicion de Fusarium subglutinans y Fusarium oxysporum in vitro. Revista Chapingo Serie Horticultura. 2005a;11:273-278. doi: 10.5154/r.rchsh.2003.12.085

30. Sood M, Kapoor D, Kumar V, et al. Trichoderma: The "Secrets" of a multitalented biocontrol agent. Plants. 2020;9:762e. doi: 10.3390/plants9060762

31. Hyder S, Inam UH, Bibi S, Humayun A, Ghuffar S, Iqbal S. Novel potential of Trichoderma spp., as biocontrol agent. J Entomol Zool Stud. 2017;5(4):214-222.

32. Huallanca VCA, Cadenas GCA. Control de Phytophthora capsici Leonian en Capsicum annuum cv. Papri king con fungicidas, fertilizantes y biocontroladores. Anales Cientificos. 2014;75(1):130-137. doi: 10.21704/ ac.v75i1.943

33. Madhavi M, Kumar CPC, Reddy DRR, Singht TK. Integrated management of wilt of chilli incited by Fusarium solani. Indian J Plant Prot. 2006;34(2):225228.

34. Agrios GN. Plant Pathology: 5Ed. Elsevier the Academic Press. London. 2006:838. 